\title{
KEEFEKTIFAN SUPERVISI AKADEMIK KEPALA SMK NEGERI KELOMPOK TEKNOLOGI DAN REKAYASA DI KABUPATEN KEBUMEN
}

\author{
Subagiyo Budi Wahono, Cepi Safrudin Abdul Jabar \\ SMK Negeri 2 Kebumen, Fakultas Ilmu Pendidikan Universitas Negeri Yogyakarta \\ subagiyo2703@yahoo.com, cepi_safruddin@yahoo.ac.id
}

\begin{abstract}
Abstrak
Penelitian ini bertujuan untuk mengetahui persepsi guru dan persepsi kepala sekolah terhadap keefektifan supervisi akademik kepala sekolah yang meliputi perencanaan, pelaksanaan, tindak lanjut supervisi akademik terhadap kinerja guru. Penelitian ini bersifat deskriptif kuantitatif. Populasi penelitian ini adalah kepala sekolah dan guru pada 4 (empat) Sekolah Menengah Kejuruan Negeri Kelompok Teknologi dan Rekayasa di Kabupaten Kebumen. Semua kepala sekolah dijadikan subyek penelitian. Sedangkan untuk guru diambil dengan teknik simple Random Sampling sejumlah 142 orang. Pengambilan data pada penelitian ini dengan angket dan wawancara sebagai pendukung atau cross check. Uji validitas instrumen dengan menggunakan Pearson Correlation. Data kuantitatif diolah secara deskriptif dengan bantuan SPSS 16.0 for window. Hasil penelitian menunjukkan bahwa: (1) Perencanaan supervisi akademik menunjukkan sangat efektif, (2) Pelaksanaan supervisi akademik menunjukkan kategori efektif, (3) Tindak lanjut supervisi akademik menunjukkan kategori efektif.
\end{abstract}

Kata kunci: kepala sekolah, supervisi akademik, Sekolah Menengah Kejuruan

\section{THE EFFECTIVENESS OF SCHOOL PRINCIPAL ACADEMIC SUPERVISION OF STATE SMK AT ENGINEERING AND TECHNOLOGY DEPARTMENT AT KEBUMEN REGENCY}

\author{
Subagiyo Budi Wahono, Cepi Safrudin Abdul Jabar \\ SMK Negeri 2 Kebumen, Fakultas Ilmu Pendidikan Universitas Negeri Yogyakarta \\ subagiyo2703@yahoo.com,cepi_safruddin@yahoo.ac.id
}

\begin{abstract}
This research aimed to know perceptions of teachers and principals perceptions of the effectiveness of school principal academic supervision which covers planning, implementing, following-up academic supervision on teacher is performance. This research has a quantitative descriptive characteristic. This research population was principals and teachers of four State Vocational Schools at Technology and Engineering Department at Kebumen Regency. All school principals became the subject of the research. Meanwhile the teacher is taken by Simple Random Sampling technique of 142 people. The data sampling at this research is with questionnaire and interview as support or cross check. The instrument validity test is by using Pearson Correlation. The quantitative data is processed descriptively by the help of SPPS 16.0 for window. The result of research shows that: (1) Academic Supervision Plan shows very effective category, (2) Academic supervision implementation shows effective category, (3) Academic supervision follow-up shows effective category.

Keywords: school principal, academic supervision, Vocational High School
\end{abstract}




\section{Pendahuluan}

Dalam Undang-Undang Republik Indonesia Nomor 20 tahun 2003 Bab XI pasal 40 ayat $2 \mathrm{~b}$ disebutkan bahwa "pendidik dan tenaga kependidikan berkewajiban mempunyai komitmen secara profesional untuk meningkatkan mutu pendidikan". Dari pasal tersebut diketahui bahwa pendidik atau sering disebut guru dituntut melaksanakan kewajiban profesionalnya dalam rangka meningkatkan mutu pendidikan, karena guru adalah pelaku utama dalam pelaksanaan pembelajaran. Sejalan dengan tuntutan undang-undang tersebut seringkali dipandang bahwa lulusan tergantung pada peranan guru dalam pengelolaan komponen pengajaran yang terlibat didalam proses belajar mengajar dan yang menjadi tanggung jawab sekolah.

Undang Undang RI No 14 tahun 2005 tentang Guru dan Dosen bab III, pasal 7 menyebutkan: Profesi guru merupakan bidang pekerjaan khusus yang dilaksanakan berdasarkan prinsip sebagai berikut: memiliki bakat, minat panggilan jiwa, dan idealisme, memiliki komitmen untuk meningkatkan mutu pendidikan, keimanan, ketakwaan, dan akhlak mulia, memiliki kualifikasi akademik dan latar belakang pendidikan sesuai dengan bidang tugas, memiliki kompetensi yang diperlukan sesuai dengan bidang tugas, memiliki tanggung jawab atas pelaksanaan tugas keprofesionalan.

Mengingat peran guru yang besar dalam proses pendidikan, maka guru perlu mempunyai pengetahuan yang sesuai dengan tuntutan bidang tugasnya. Guru perlu mendapatkan bimbingan, pembinaan dari kepala sekolah agar kemampuannya terus berkembang. Guru memiliki tugas utama (1) membuat program pembelajaran; (2) melaksanakan program pembelajaran; (3) melaksanakan evaluasi; (4) melaksanakan analisis hasil belajar siswa; (5) melaksanakan perbaikan, remedial, dan pengayaan. Tidak semua guru mampu melaksanakan tugas utama itu. Banyak faktor yang mempengaruhi. Dua faktor utama adalah kemampuan dan kemauan. Agar tugas tersebut dapat dilaksanakan dengan baik maka perlu dorongan, pengawasan dan pembinaan dari kepala sekolah.

Tugas pengawasan dan pembinaan guru menjadi wewenang dan tanggung jawab kepala sekolah. Kepala sekolah sebagai atasan langsung dituntut memiliki kapasitas utama sebagai edukator, manajer, administrator, supervisor, leader, inovator, dan motivator. Salah satu program yang dapat diselenggarakan dalam usaha pembinaan guru untuk mencapai tujuan sekolah adalah supervisi akademik. Kepala sekolah sebagai pemimpin pendidikan mempunyai tugas dibidang administrasi dan tugas di bidang supervisi. Tugas dibidang supervisi adalah tugas kepala sekolah yang berkaitan dengan pembinaan guru untuk perbaikan pengajaran. Supervisi merupakan suatu usaha memberikan bantuan kepada guru untuk memperbaiki atau meningkatkan proses dan situasi belajar mengajar. Sasaran akhir dari kegiatan supervisi adalah meningkatkan hasil belajar siswa.

Glickman dalam Dirjen PMPTK Kemendiknas (2010, p.7) mendefinisikan supervisi akademik adalah serangkaian kegiatan membantu guru mengembangkan kemampuannya mengelola proses pembelajaran untuk mencapai tujuan pembelajaran. Pidarta (2009, p. 2) Supervisi adalah kegiatan membina para pendidik dalam mengembangkan proses pembelajarannya, termasuk segala unsur penunjangnya Dasrizal (2009, p.9) supervisi akademik adalah serangkaian usaha pemberian bantuan kepada guru dalam bentuk layanan profesional yang diberikan oleh supervisor (pengawas, kepala sekolah) guna meningkatkan mutu proses dan hasil belajar mengajar. Sullivan dan Glanz (2005, p. 27) mengemukakan bahwa "supervision is the process of engaging teachers in instructional dialogue for the purpose of improving teaching and increasing student achievement" yang maksudnya supervisi adalah proses pelibatan guru dalam dialog tentang pembelajaran yang bertujuan mengembangkan kemampuan mengajar serta meningkatkan keberhasilan siswa. Purwanto (2012, p.76) supervisi adalah suatu aktivitas pembinaan yang diren- 
canakan untuk membantu para guru dan pegawai sekolah lainnya dalam melakukan pekerjaan mereka secara efektif.

Supervisi akademik yang baik adalah supervisi yang mampu menghantarkan guru-guru menjadi semakin kompeten. Dalam Peraturan Menteri Pendidikan Nasional No. 13 tahun 2007 tentang standar kompetensi kepala sekolah disebutkan “ dimensi Kompetensi kepala sekolah terdiri dari Kepribadian, Manajerial, Kewirausahaan, Supervisi, dan Sosial". Adapun supervisi akademik esensinya berkenaan dengan tugas kepala sekolah untuk membina guru dalam meningkatkan mutu pembelajarannya, sehingga pada akhirnya dapat meningkatkan prestasi belajar siswa.

Menurut Permendiknas No.13 tahun 2007 dimensi kompetensi supervisi meliputi: merencanakan program supervisi akademik dalam rangka peningkatan kinerja guru, melaksanakan supervisi akademik terhadap guru dengan menggunakan pendekatan dan teknik supervisi yang tepat, menindak lanjuti hasil supervisi akademik terhadap guru dalam rangka peningkatan kinerja guru.

Kepala sekolah berkewajiban melakukan supervisi sesuai prosedur dan teknik-teknik yang tepat dan mampu melakukan monitoring, evaluasi dan pelaporan program pendidikan sesuai dengan prosedur yang tepat. Keberhasilan guru dalam mengajar karena adanya supervisi kepala sekolah sehingga termotivasi dalam bekerja akan meningkatkan kualitas hasil belajar siswa. Guru merupakan salah satu faktor penentu tinggi rendahnya mutu dan hasil pendidikan, maka setiap usaha peningkatan mutu pendidikan perlu memberikan perhatian besar kepada peningkatan kinerja guru. Guru dituntut memiliki kinerja yang mampu memberikan dan merealisasikan harapan dan keinginan semua pihak terutama masyarakat umum yang telah mempercayai sekolah dan guru dalam membina anak didik.

Untuk meraih mutu pendidikan yang baik sangat dipengaruhi oleh kinerja guru dalam melaksanakan tugasnya sehingga kinerja guru menjadi tuntutan penting untuk mencapai keberhasilan pendidikan. Secara umum mutu pendidikan yang baik menjadi tolok ukur bagi keberhasilan kinerja yang ditunjukkan guru. Tugas guru erat kaitannya dengan peningkatan sumber daya manusia melalui sektor pendidikan, oleh karena itu perlu upaya-upaya untuk meningkatkan kinerja guru agar menjadi tenaga yang profesional. Untuk meningkatkan kinerja guru maka perlu diadakan pembinaan secara terus menerus dan berkesinambungan. Salah satu upaya untuk meningkatkan kinerja guru yaitu melalui supervisi akademik, dengan adanya supervisi akademik maka guru akan mendapatkan umpan balik dari kepala sekolah, sehingga guru dapat meningkatkan kinerja dan memperbaiki kekurangannya. Masalah mutu pembelajaran, menyangkut masalah esensial yaitu masalah kualitas mengajar yang dilakukan guru harus mendapat pengawasan dan pembinaan terus menerus dan berkelanjutan.

Lopez (2007, p. 49) menyatakan " $a$ teacher capacity is the skills abilities, and knowledge derived from his or her training and experiences relevant to students learning need". Kapasitas guru adalah kemampuan keterampilan, dan pengetahuan yang berasal dari dalam dirinya atau pelatihan dan pengalaman yang relevan dengan kebutuhan belajar siswa. Tugas pengawasan dan pembinaan guru menjadi wewenang dan tanggung jawab kepala sekolah.

Kepala sekolah adalah pemimpin satuan pendidikan yang bertugas melaksanakan administrasi, pengelolaan, pengembangan, pengawasan, dan pelayanan teknis untuk menunjang proses pendidikan pada satuan pendidikan yang dipimpinnya. Sebagai pemimpin pendidikan di sekolah, kepala sekolah memiliki tanggung jawab legal untuk mengembangkan staf, kurikulum, dan pelaksanaan pendidikan disekolahnya.

Berdasarkan hasil survei awal wawancara dengan beberapa guru di Sekolah Menengah Kejuruan Negeri Keelompok Teknologi dan Rekayasa di Kabupaten Kebumen belum diketahui ada informasi tentang keefektifan supervisi akademik oleh kepala sekolah. Ada beberapa hal 
yang belum sesuai dalam pelaksanaan supervisi akademik. Belum semua guru memahami tujuan supervisi akademik. Supervisi akademik belum menjadi kebutuhan guru. Kegiatan supervisi akademik oleh sebagian guru dirasakan sebagai beban atau sesuatu yang tidak menyenangkan. Berbagai upaya telah di lakukan oleh kepala sekolah dalam meningkatkan kinerja guru, namun masih menemui berbagai kendala diantaranya masih ada guru yang kurang disiplin dalam menjalankan tugas, masih ada guru dalam mengajar belum menggunakan metode dan media pembelajaran yang bervariasi.

Permasalahan lain yaitu sebagian guru belum memiliki kompetensi profesional yang memadai dan belum memiliki komitmen yang tinggi terhadap profesionalisme guru. Makawimbang (2011, p. 134) menyatakan bahwa "guru yang profesional adalah mereka yang memiliki kemampuan profesional dengan berbagai kapasitasnya sebagai pendidik". Guru yang profesional amat berarti bagi pembentukan sekolah unggulan. Guru profesional memiliki pengalaman mengajar, kapasitas intelektual, moral, keimanan, ketakwaan, disiplin, tanggungjawab, wawasan kependidikan yang luas, kemampuan manajerial, terampil, kreatif, memiliki keterbukaan profesional dalam memahami potensi, karakteristik dan masalah perkembangan peserta didik, mampu mengembangkan rencana studi dan karir peserta didik serta memiliki kemampuan meneliti dan mengembangkan kurikulum. Kurangnya kompetensi ini tercermin kurangnya guru yang belum dapat mengembangkan materi secara kreatif serta lemahnya penggunaan teknologi informasi dan komunikasi secara tepat.

Guru harus meningkatkan kompetensi professional yang berhubungan dengan ketrampilan dan metode mengajar yang bervariasi, penggunaan media pembelajaran dan kegiatan pembelajaran yang menyenangkan. Apabila guru dapat menguasai kompetensi secara baik akan menjadi penentu dan memegang peranan penting dalam keberhasilan pendidikan karena guru menjadi pusat dan motor pendidikan dalam proses belajar mengajar.

Supervisi akademik adalah membina guru dalam meningkatkan mutu pembelajaran. Sasaran supervisi akademik adalah guru dalam melaksanakan proses pembelajaran, penyusunan silabus dan RPP, pemilihan strategi/metode/teknik pembelajaran, penggunaan media dan teknologi informasi dalam pembelajaran, menilai proses dan hasil pembelajaran serta penelitian tindakan kelas (Kemendiknas, 2010, p. 6).

Masalah supervisi penting untuk diketahui mengingat efektifitas supervisi akademik tersebut menjadi kunci keberhasilan supervisi sebagai sarana peningkatan mutu pembelajaran. Kemudian dari sisi kinerja guru belum semua guru mempersiapkan perangkat pembelajaran seperti program semester, program tahunan, silabus dan Rencana Pelaksanaan Pembelajaran (RPP) tepat pada awal semester, kemudian juga masih terdapat proses pembelajaran yang monoton yang berpusat pada guru kurang melibatkan siswa aktif dalam proses pembelajaran, belum menggunakan media dan metode pembelajaran yang beragam sehingga kurang menarik dan membosankan yang akhirnya layanan belajar pada peserta didik kurang berkualitas. Dengan demikian untuk meningkatkan kinerja guru dan pengembangan guru maka sangatlah diperlukan bimbingan dan pembinaan dari kepala sekolah, yaitu melalui supervisi akademik.

Masalah-masalah klasik masih saja menghantui sekolah-sekolah kita,seperti putus sekolah, tinggal kelas, proses belajar mengajar yang kurang bermutu dan kurang relevan, semangat belajar yang rendah, disiplin guru dan murid yang masih kurang, dimana sekolah belum mampu menjadi organisasi pembelajaran yang efektif untuk meningkatkan prestasi.

Supervisi yang efektif merupakan faktor penting untuk ikut meningkatkan produktivitas kerja. Agar supervisi menjadi efektif maka perlu kerja sama antara kepala sekolah dengan guru. Hal ini senada dengan pendapat Hawkins \& Shohet (2012, p. 36) "supervision can be become a 
more effective and satisfying activity for both supervisor and supervisees in any setting if there is an explicit contract which can form the basis of the supervisory alliance". Kegiatan supervisi akademik yang dilakukan kepala sekolah merupakan bantuan profesional yang sangat dibutuhkan guru untuk mengembangkan kemampuan profesionalnya.

Terkait dengan adanya permasalahan tersebut diatas, maka dalam penelitian ini akan dikaji persepsi guru dan kepala sekolah terhadap keefektifan supervisi akademik yang dilakukan oleh kepala sekolah.

Dari uraian permasalahan tersebut dapat diidentifikasi permasalahan yang ada yaitu belum semua guru mengembangkan kompetensi profesionalnya dalam proses belajar mengajar, belum semua guru memahami tujuan supervisi, belum semua guru menggunakan metode dan media pembelajaran yang bervariasi, persepsi guru terhadap supervisi akademik kurang mendukung, guru belum menerima pelaksanaan supervisi akademik dengan senang hati, dan belum merupakan kebutuhan untuk perbaikan dan pengembangan diri, melainkan dirasa sebagai beban.

Penelitian ini bertujuan untuk mengetahui keefektifan supervisi akademik oleh Kepala Sekolah Menengah Kejuruan Negeri Kelompok Teknologi dan Rekayasa di Kabupaten Kebumen, namun secara khusus untuk mengetahui persepsi guru dan persepsi kepala sekolah terhadap keefektifan perencanaan supervisi akademik yang dilakukan oleh kepala sekolah, keefektifan sasaran supervisi akademik yang dilakukan oleh kepala sekolah, keefektifan tindak lanjut supervisi akademik yang dilakukan oleh kepala sekolah.

Penelitian diharapkan dapat bermanfaat bagi guru-guru SMK, dalam memahami hal-hal yang berkaitan dengan supervisi akademik sehingga dapat mengembangkan kompetensinya, dan bagi kepala sekolah dapat sebagai informasi atau masukan mengenai pentingnya kegiatan supervisi akademik meliputi perencanaan, pelaksanaan dan tindak lanjut sehingga proses kegiatan belajar mengajar dapat berjalan dengan baik.

\section{Metode Penelitian}

Penelitian ini berjenis deskriptif kuantitatif yang bertujuan untuk menggambarkan dan mengungkapkan suatu masalah, keadaan peristiwa sebagaimana adanya. Penelitian ini untuk mengetahui nilai variabel secara mandiri, tanpa membuat perbandingan atau menghubungkan antara variabel satu dengan variabel lain.

Desain dalam penelitian ini adalah pendekatan ex post facto yaitu tidak mengadakan perlakuan terhadap subjek yang menjadi sasaran penelitian melainkan hanya menggali fakta-fakta yang peristiwanya telah terjadi. Dalam penelitian ini yaitu keefektifan supervisi akademik menggunakan data kuantitatif dengan angket yang disampaikan kepada kepala sekolah dan guru, sedangkan untuk menambah data cross chek menggunakan wawancara dengan kepala sekolah. Penelitian ini mengungkap fakta berdasarkan pengukuran gejala yang terjadi pada diri responden tanpa manipulasi dari peneliti.

Penelitian dilaksanakan di SMK Negeri Kelompok Teknologi dan Rekayasa yang ada di kabupaten Kebumen yang terdiri dari: SMK N 1 Gombong, SMK N 1 Ambal, SMK N 1 Puring dan SMK N Karanggayam. Penelitian dilaksanakan pada Bulan April 2014 sampai bulan Mei 2014. Populasi penelitian adalah semua Kepala Sekolah dan guru SMK Negeri di Kabupaten Kebumen yang berjumlah untuk kepala sekolah 4 orang, dan untuk guru 221 yang tersebar di 4 SMK Negeri.

Sampel diambil dengan teknik Simple Random Sampling yaitu pengambilan anggota sampel dari populasi dilakukan secara acak tanpa memperhatikan strata yang ada dalam populasi, anggota populasi dianggap homogen. Jumlah anggota sampel sering dinyatakan dengan ukuran sampel (Sugiyono, 2012, p. 126). Penentuan ukuran sampel dalam penelitian ini dilakukan dengan rumus Slovin sebagai berikut.

Keterangan:

$$
n=\frac{N}{1+N e^{2}}
$$

$\mathrm{n}=$ ukuran sampel

$\mathrm{N}=$ ukuran populasi 
e = kelonggaran ketidaktelitian karena kesalahan pengambilan sampel yang ditololerir.

Batas kesalahan yang ditolelir ini untuk setiap populasi tidak sama, ada yang $1 \%, 2 \%, 3 \%, 4 \%, 5 \%$, atau $10 \%$.

Berdasarkan Rumus Slovin tersebut dengan batas kesalahan diambil 5\%, maka sampel penelitiannya 142 untuk guru dan untuk kepala sekolah karena hanya 4 kita jadikan sampel semua.

Variabel penelitian ini adalah satu yaitu supervisi akademik kepala sekolah dengan subvariabel perencanaan supervisi, pelaksanaan supervisi akademik dan tindak lanjut supervisi akademik.

Penelitian ini untuk melihat keefektifan supervisi akademik yang dilakukan oleh Kepala Sekolah Menengah Kejuruan Negeri Kelompok Teknologi dan Rekayasa di Kabupaten Kebumen berdasarkan persepsi guru dan kepala sekolah.

Pengumpulan data pada penelitian ini dilakukan dengan menggunakan angket dan wawancara. Untuk mendapatkan data yang di perlukan sesuai dengan tujuan penelitian diperlukan suatu alat pengumpul data yang disebut instrumen penelitian. Instrumen penelitian yang diperlukan adalah angket/kuesioner yang di susun secara sistematik dengan lebih dulu diuji validitas dan reliabilitasnya. Angket atau kuesioner adalah sejumlah pertanyaan atau pernyataan tertulis yang digunakan untuk mendapatkan informasi dari responden..

Angket yang disusun dalam penelitian ini berisi pernyataan tentang perencanaan supervisi oleh kepala sekolah, pelaksanaan supervisi oleh kepala sekolah, teknik supervisi, pendekatan supervisi, sasaran supervisi dan umpan balik atau tindak lanjut hasil supervisi oleh kepala sekolah kepada guru. Jenis angket adalah berstruktur dengan pertanyaan yang disusun dengan sejumlah alternatif jawaban. Dengan demikian responden hanya diberi kesempatan untuk memberikan jawaban yang paling sesuai dengan persepsinya. Penyusunan angket dalam penelitian ini berdasarkan kisi-kisi variabel penelitian yaitu variabel supervisi akademik dan sasaran supervisi mengenai proses pembelajaran yang dilaksankan oleh guru. Angket menggunakan Skala Likert, sedangkan bentuk angket dalam penelitian ini berupa pilihan dengan alternatif empat jawaban. yaitu: Selalu (Sl), Sering (Sr), Kadang-kadang (K), Tidak pernah (Tp).

Wawancara dilakukan untuk mengetahui hal-hal dari responden secara mendalam dan untuk menguatkan hasil data yang diperoleh dari kuisioner yang telah disebarkan. Wawancara yang dilakukan adalah wawancara terstruktur (dilakukan melalui pertanyaan-pertanyaan yang telah disiapkan sesuai dengan permasalahan yang akan diteliti).

Menurut Sugiyono (2012, p. 173) instrumen yang valid berarti alat ukur yang digunakan untuk mendapatkan data valid. Valid berarti instrumen tersebut dapat dugunakan untuk mengukur apa yang seharusnya diukur. Setiap penyusunan instrumen dalam penelitian selalu memperhitungkan beberapa pertimbangan seperti apa yang hendak diukurnya, apakah data yang terkumpul relevan dengan sifat atau karakteristiknya yang dikehendaki dan sejauh mana perbedaan skor yang diperoleh menggambarkan karakteristik yang akan diukur.

Hasil penelitian yang valid bila terdapat kesamaan antara data yang terkumpul dengan data yang sesungguhnya terjadi pada objek yang diteliti. Sedangkan reliabel artinya dapat dipercaya, dapat diandalkan. Dengan menggunakan instrumen yang valid dan reliabel dalam pengambilan data diharapkan penelitian ini menjadi valid dan reliabel.

Uji Validitas menggunakan rumus korelasi Product Moment :

$$
r_{x y}=\frac{n\left(\sum X Y\right)-\left(\sum X\right)\left(\sum Y\right)}{\sqrt{\left[n\left(\sum X^{2}\right)-\left(\sum X\right)^{2} \mid n\left(\sum Y^{2}\right)-\left(\sum Y\right)^{2}\right]}}
$$

Dimana:

$r_{x y}=$ koefisien korelasi suatu butir/item

$\mathrm{N}=$ jumlah subyek

$\mathrm{X}=$ skor suatu butir/item 
$\mathrm{Y}=$ skor total

(Arikunto, 2010, p. 317)

Nilai $r$ kemudian dikonsultasikan dengan $r_{\text {tabel }}\left(r_{\text {kritis }}\right)$. Bila $r_{\text {hitung }}$ dari rumus di atas lebih besar dari $r_{\text {tabel }}$ maka butir tersebut valid, tetapi jika $r$ hitung lebih kecil dari $r$ tabel maka instrumen tersebut gugur. Uji Validitas Instrumen penelitian ini dilakukan terhadap 30 responden (Sugiyono, 2012 , p. 177). Jumlah responden $(n)=30$, besarnya koefisien korelasi pada tabel dengan taraf signifikan 0,05\% diperoleh angka sebesar 0,361 (Sugiyono, 2012, p. 455). Dengan demikian item instrumen yang dianggap valid adalah item yang koefisien korelasinya lebih besar atau sama dengan $(\geq)$ 0,361. Dari hasil uji coba instrumen diketahui ada bebrapa butir instrumen yang tidak valid. Butir instrumen yang tidak valid kemudian tidak dipakai, karena sudah bisa terwakili oleh butir yang lainnya.

Reliabilitas dapat didefinisikan sebagai derajat ketepatan dan ketelitian atau akurasi. Sedangkan reliabilitas menggunakan koefisien alpha sebagai berikut:

$$
r_{11}=\left[\frac{k}{k-1}\right]\left[1-\frac{\sum \sigma_{b}^{2}}{V_{t}^{2}}\right]
$$

Dimana:

$r_{11} \quad=$ reliabilitas instrumen

$\mathrm{K}$ = banyaknya butir pertanyaan atau banyaknya soal

$\sum \sigma_{b}^{2}=$ jumlah varian butir/item

$V_{t}^{2} \quad=$ varian total

Kriteria suatu instrumen penelitian dikatakan reliabel dengan menggunakan teknik ini, bila koefisien reliabilitas $\left(r_{11}\right)>$ 0,6 . Berdasarkan hasil analisis, semua variabel memiliki indeks reliabilitas lebih dari 0,6 . Dengan demikian, instrumen ini dapat dikatakan memiliki keterandalan dan dapat digunakan untuk mengumpulkan data.

Teknik analisis data dalam penelitian ini adalah deskriptif kuantitatif yaitu mendeskripsikan dan memaknai data tiap-tiap komponen kemudian disesuaikan dengan acuan kriteria yang telah ditentukan. Kegiatan dalam analisa data adalah menge- lompokkan data berdasarkan variabel, mentabulasi data berdasarkan variabel dari seluruh responden, menyajikan data tiap variabel yang diteliti, melakukan perhitungan untuk menjawab rumusan masalah (Sugiyono, 2008, p.147).

Data dianalisis menggunakan SPSS 16 for windows. Adapun langkahnya sebagai berikut. Sebelum angket keefektifan supervisi akademik disebarkan pada responden yang sebenarnya maka terlebih dahulu dilakukan uji coba angket. Uji coba angket dilakukan terhadap 30 responden yang terdiri dari 29 orang guru dan 1 orang kepala sekolah. Uji coba angket dilakukan diluar tempat yang akan diteliti, yaitu di SMK Negeri 2 Kebumen. Uji coba angket tersebut ditujukan untuk mengetahui validitas angket. Validitas dilakukan melalui konsultasi dengan para ahli (Expert judgment) dalam hal ini dosen pembimbing. Melalui konsultasi dengan ahli ini maka angket dianalisa terhadap susunan kalimat maupun isi angket berkaitan dengan permasalahan yang akan diteliti. Uji validitas juga dilakukan melalui hasil uji coba angket yang telah diisi oleh responden.

Angket yang telah dinyatakan valid dan reliabel kemudian disebarkan kepada responden sebanyak 4 kepala sekolah dan 142 guru. Angket yang disebarkan berisi 49 butir pernyataan/pertanyaan yang terdiri dari 8 butir pernyataan/pertanyaan mengenai perencanaan supervisi akademik, 34 butir pernyataan tentang pelaksanaan supervisi akademik, dan 7 butir pernyataan mengenai tindak lanjut supervisi akademik. Dari 142 angket yang disebarkan semuanya diisi dan kembali, hanya membutuhkan waktu yang agak lama sekitar satu bulan, karena angket disebarkan setelah kelas XII menempuh ujian, sehingga untuk guru kelas XII agak sulit ditemui, karena jarang hadir ke sekolah. Peneliti mengumpulkan instrumen angket yang telah diisi oleh responden. Adapun jawaban tiap butir angket menggunakan skala likert 4 pilihan jawaban tertutup dengan masing-masing jawaban selalu mempunyai skor 4 , sering mempunyai skor 3, kadangkadang mempunyai skor 2 , dan tidak pe- 
rnah mempunyai skor 1. Setelah instrumen dikumpulkan semua maka kemudian diberi kode dan masing-masing jawaban responden dijumlahkan dan dihitung rataratanya. Selanjutnya dibuat skala 0 sampai dengan 100. Kemudian untuk memperoleh kesesuaian dengan interval keefektifan dibandingkan nilai keefektifan hitung dengan nilai skor tertinggi kemudian dikalikan 100 adapun rumus yang digunakan adalah sebagai berikut.

$$
\text { rerata }=\frac{n}{N \times 100}
$$

$\mathrm{n}=$ jumlah skor perolehan

$\mathrm{N}=$ Jumlah skor maksimal

Dengan bantuan SPSS 16 for Windows kita cari rata-rata skor mean, median dan mode dari responden. Rekomendasi yang diberikan terhadap pencapaian keefektifan berpedoman pada klasifikasi pencapaian menurut pengelompokan berikut.

Tabel 1. Pencapaian Keefektifan

\begin{tabular}{clll}
\hline No Skor (\%) & Ketercapian & Rekomendasi \\
\hline 1 & $81-100$ & Baik sekali & Sangat Efektif \\
2 & $61-80$ & Baik & Efektif \\
3 & $41-60$ & Cukup & Cukup Efektif \\
4 & $21-40$ & Kurang & Kurang Efektif \\
5 & $<21$ & Kurang Sekali & Tidak Efektif \\
\hline \multicolumn{3}{l}{ (Arikunto \& Abduljabar, 2011, p. 35) }
\end{tabular}

\section{Hasil Penelitian dan Pembahasan}

Hasil penelitian ini menguraikan deskripsi data mengenai persepsi guru dan kepala sekolah terhadap keefektifan supervisi akademik oleh kepala SMK Negeri Kelompok Teknologi dan Rekayasa di Kabupaten Kebumen dalam merencanakan program supervisi akademik, pelaksanaan supervisi akademik dengan menggunakan pendekatan dan teknik yang tepat, dan tindak lanjut supervisi akademik.

Persepsi Guru dan Kepala Sekolah tentang Keefektifan Perencanaan Supervisi Akademik

Keefektifan perencanaan supervisi akademik oleh Kepala Sekolah Menengah
Kejuruan Negeri Kelompok Teknologi dan Rekayasa di Kabupaten Kebumen ini diukur dengan instrumen angket berjumlah 8 item pertanyaan. Skor pada masingmasing item pertanyaan selanjutnya dibuat dalam skala 100 atau persentase, sehingga diperoleh rentangan skor antara 0 sampai dengan 100.

Tabel 2. Statistik Deskriptif Keefektifan Perencanaan Supervisi Akademik oleh Kepala Sekolah Menengah

Kejuruan Negeri Kelompok Teknologi dan Rekayasa di Kabupaten Kebumen

\begin{tabular}{lcc}
\hline \multirow{2}{*}{$\begin{array}{c}\text { Perencanaan Program } \\
\text { supervisi akademik }\end{array}$} & \multicolumn{2}{c}{ Sumber data } \\
\cline { 2 - 3 } & Guru & $\begin{array}{c}\text { Kepala } \\
\text { Sekolah }\end{array}$ \\
\hline Mean (Rerata) & 88.20 & 90.62 \\
Median & 100.00 & 90.62 \\
Mode & 100.00 & 90.62 \\
Standart Deviasi & 16.82 & 2.55 \\
Minimum & 25.00 & 87.50 \\
Maximum & 100.00 & 93.75 \\
\hline Kategori Mean & Sangat & Sangat \\
& efektif & efektif \\
\hline
\end{tabular}

Tabel 3. Distribusi Frekuensi Keefektifan Perencanaan Supervisi Akademik oleh Kepala Sekolah menengah Kejuruan Negeri Kelompok Teknologi dan Rekayasa di Kabupaten Kebumen

\begin{tabular}{lcccc}
\hline \multirow{2}{*}{$\begin{array}{c}\text { Perencanaan } \\
\text { Supervisi } \\
\text { akademik }\end{array}$} & \multicolumn{3}{c}{ Guru } & \multicolumn{2}{c}{$\begin{array}{c}\text { Kepala } \\
\text { Sekolah }\end{array}$} \\
\cline { 2 - 5 } & $\mathrm{f}$ & $\%$ & $\mathrm{f}$ & $\%$ \\
\hline Sangat Efektif & 101 & 73 & 4 & 100 \\
Efektif & 30 & 22 & 0 & 0 \\
Cukup Efektif & 9 & 6 & 0 & 0 \\
Kurang Efektif & 2 & 1 & 0 & 0 \\
Tidak Efektif & 0 & 0 & 0 & 0 \\
\hline Total & 142 & 100 & 4 & 100 \\
\hline
\end{tabular}

Tabel 2 dan Tabel 3 memperlihatkan bahwa keefktifan perencanaan supervisi akademik oleh Kepala Sekolah Menengah Kejuruan Negeri Kelompok Teknologi dan Rekayasa di Kabupaten Kebumen berada pada kategori sangat efektif dengan tingkat 
pencapaian menurut persepsi guru reratanya sebesar 88,2 dan menurut persepsi kepala sekolah pencapaian reratanya sebesar 90,62 .

Hasil penelitian menunjukkan bahwa kepala sekolah sudah mampu dalam merencanakan program supervisi akademik. Artinya perencanaan supervisi yang di buat oleh kepala sekolah mengarah ke pembinaan untuk meningkatkan profesionalisme guru, perencanaan dibuat sesuai dengan kebutuhan guru. Hal ini sesuai dengan pendapat Makawimbang (2012, p. 80) yang menyatakan bahwa kepala sekolah merencanakan program supervisi akademik sesuai dengan kebutuhan guru. Seorang kepala sekolah yang akan melaksanakan supervisi harus menyiapkan perlengkapan supervisi, tujuan, sasaran, objek, metode, teknik dan pendekatan yang direncanakan, serta instrumen yang sesuai, berupa format-format supervisi (Depdiknas, 2011, p. 12).

Perencanaan merupakan hal sangat penting dari setiap kegiatan. Tanpa perencanaan yang baik maka kegiatan tersebut tidak akan berjalan dengan baik. Agar kepala sekolah dapat melaksanakan tugasnya dengan baik, maka kepala sekolah harus memiliki kompetensi membuat rencana program supervisi akademik (Depdiknas, 2011, p. 10). Manfaat perencanaan program supervisi akademik adalah sebagai berikut: sebagai pedoman pelaksanaan dan pengawasan supevisi akademik, untuk menyamakan persepsi seluruh warga sekolah tentang program supervisi akademik, penjamin penghematan serta keefektifan penggunaan sumber daya sekolah (tenaga, waktu dan biaya).

Persepsi Guru dan Kepala Sekolah tentang Keefektifan Pelaksanaan Supervisi Akademik

Keefektifan perencanaan supervisi akademik oleh Kepala Sekolah Menengah Kejuruan Negeri Kelompok Teknologi dan Rekayasa di Kabupaten Kebumen ini diukur dengan instrumen angket berjumlah 38 item pertanyaan. Skor pada masingmasing item pertanyaan selanjutnya dibuat dalam skala 100 atau persentase, sehingga diperoleh rentangan skor antara 0 sampai dengan 100.

Tabel 4. Statistik Deskriptif Keefektifan Pelaksanaan Supervisi Akademik oleh Kepala Sekolah menengah

Kejuruan Negeri Kelompok Teknologi dan Rekayasa di Kabupaten Kebumen

\begin{tabular}{lcc}
\hline \multirow{2}{*}{$\begin{array}{c}\text { Pelaksanaan Supervisi } \\
\text { Akademik }\end{array}$} & \multicolumn{2}{c}{ Sumber data } \\
\cline { 2 - 3 } Mean (Rerata) & 77.02 & 79.96 \\
Median & 79.41 & 79.77 \\
Mode & 79.41 & 79.41 \\
Standart Deviasi & 12.01 & 0.703 \\
Minimum & 30.88 & 79.41 \\
Maximum & 97.06 & 80.88 \\
\hline Kategori Mean & efektif & efektif \\
\hline
\end{tabular}

Tabel 5. Distribusi Frekuensi Distribusi Frekuensi Keefektifan Pelaksanaan Supervisi Akademik oleh Kepala Sekolah menengah Kejuruan Negeri Kelompok Teknologi dan Rekayasa di Kabupaten Kebumen

\begin{tabular}{lcccc}
\hline \multirow{2}{*}{$\begin{array}{c}\text { Pelaksanaan } \\
\text { Supervisi } \\
\text { Akademik }\end{array}$} & \multicolumn{3}{c}{ Guru } & \multicolumn{2}{c}{$\begin{array}{c}\text { Kepala } \\
\text { Sekolah }\end{array}$} \\
\cline { 2 - 5 } & & & $\mathrm{f}$ & $\%$ \\
\cline { 2 - 5 } Sangat Efektif & 63 & 44 & 0 & 0 \\
Efektif & 65 & 46 & 4 & 100 \\
Cukup Efektif & 13 & 9 & 0 & 0 \\
Kurang Efektif & 1 & 1 & 0 & 0 \\
Tidak Efektif & 0 & 0 & 0 & 0 \\
\hline Total & 142 & 100 & 4 & 100 \\
\hline
\end{tabular}

Tabel 4 dan 5 memperlihatkan bahwa keefektifan pelaksanaan supervisi akademik oleh Kepala Sekolah Menengah Kejuruan Negeri Kelompok Teknologi dan Rekayasa di Kabupaten Kebumen berada pada kategori efektif dengan tingkat pencapaian menurut persepsi guru reratanya sebesar 77,02 dan menurut persepsi kepala sekolah pencapaian reratanya sebesar 79,96.

Hal tersebut berarti bahwa kepala sekolah sudah mempunyai pengetahuan dalam memilih prinsip, teknik, pendekatan 
supervisi yang sesuai dengan kebutuhan guru. Hal ini sesuai dengan pendapat Panigrahi $(2012$, p. 65) yang menyatakan:

Teachers must feel that the supervisor is there to serve them and to help them become more effective teachers. In order to ensure improved supervision practices, supervisory officials should be acquainted themselves with numerous of supervision models, techniques and principles"

Maksud dari pernyataan tersebut adalah guru merasa bahwa supervisor yang ada untuk melayani mereka dan untuk membantu mereka menjadi guru yang lebih efektif. Dalam rangka untuk memastikan peningkatan pengawasan praktek, supervisor harus mengetahui model supervisi, teknik dan prinsip. Dalam melakukan supervisi kepala sekolah menerapkan berbagai teknik. Teknik yang sering dipakai adalah teknik kelompok. Untuk teknik individual yaitu dengan kunjungan kelas dilaksanakan satu kali dalam satu semester. Data penelitian menunjukkan bahwa dalam penerapan teknik supervisi sebagian besar responden $(48,5 \%)$ menyatakan bahwa kepala sekolah selalu menerapkan pendekatan sesuai karakteristik guru .

Pidarta (2009, pp. 145-148) ada empat kategori guru yaitu guru lemah, guru energik, guru konseptor, guru profesional. Keempat kategori tersebut didekati dan ditangani secara berbeda-beda dalam proses supervisi yaitu: (1) pendekatan tidak langsung dan metode menilai diri sendiri diterapkan kepada guru yang termasuk kategori professional; (2) pendekatan kolaborasi dan metode berdasarkan kontrak diterapkan $\mathrm{p}$ ada guru kategor i energik dan konseptor; (3) pendekatan langsung dan metode standar diterapkan pada guru yang termasuk kategori lemah. Begitu juga yang dilaksanakan kepala sekolah dalam melaksanakan pendekatan supervisi, untuk guru yang professional dan energik diberi kesempatan yang seluas-luasnya untuk mengembangkan kompetensinya.

Untuk yang kategori guru lemah banyak digunakan pendekatan sebagai mitra kerja dan secara kekeluargaan, dengan maksud agar tidak rendah diri dan tetap semangat dalam menjalankan tugasnya, dengan selalu mendapatkan bimbingan. Dalam melakukan supervisi seorang kepala sekolah dapat menggunakan berbagai pendekatan sesuai dengan keadaan dan kompetensi guru yang akan disupervisi. Oleh karena itu seorang kepala sekolah sebelum menentukan pilihan pendekatan supervisi yang akan digunakan harus mengetahui karakteristik guru terlebih dahulu. Dengan mengetahui karakteristik dan keadaan guru yang akan disupervisi dapat digunakan untuk menetukan pendekatan yang akan digunakan dalam supervisi.

Sasaran supervisi akademik adalah guru dalam melaksanakan proses pembelajaran, penyusunan silabus dan RPP, pemilihan strategi/metode/teknik pembelajaran, penggunaan media dan teknologi informasi dalam pembelajaran, menilai proses dan hasil pembelajaran serta penelitian tindakan kelas (Kemendiknas, 2010, p.6). Dalam melaksanakan supervisi kepala sekolah mengamati administrasi guru, penmapilan guru di kelas.

Hal ini sesuai dengan yang dikemukakan Makawimbang (2011, p. 77) yang menyatakan bahwa tujuan supervisi adalah perbaikan dan perkembangan proses belajar mengajar secara total, pemberian bimbingan dan pembinaan dalam hal implentasi kurikulum, pemilihan dan penggunaan metode mengajar, alat-alat pelajaran, prosedur dan teknik evaluasi pengajaran, dan sebagainya.

Persepsi Guru dan Kepala Sekolah tentang Keefektifan Tindak Lanjut Supervisi Akademik

Keefektifan tindak lanjut supervisi akademik oleh Kepala Sekolah Menengah Kejuruan Negeri Kelompok Teknologi dan Rekayasa di Kabupaten Kebumen ini diukur dengan instrumen angket berjumlah 7 item pertanyaan. Skor pada masing-masing item pertanyaan selanjutnya dibuat dalam skala 100 atau persentase, sehingga diperoleh rentangan skor antara 0 sampai dengan 100. 
Tabel 6. Statistik Deskriptif Keefektifan Tindak Lanjut Supervisi Akademik oleh Kepala Sekolah menengah Kejuruan Negeri Kelompok Teknologi dan Rekayasa di Kabupaten Kebumen

\begin{tabular}{lcc}
\hline \multirow{2}{*}{$\begin{array}{c}\text { Tindak Lanjut Supervisi } \\
\text { Akademik }\end{array}$} & \multicolumn{2}{c}{ Sumber data } \\
\cline { 2 - 3 } & Guru & $\begin{array}{c}\text { Kepala } \\
\text { Sekolah }\end{array}$ \\
\hline Mean (Rerata) & 75 & 79.46 \\
Median & 75 & 78.57 \\
Mode & 75 & 78.57 \\
Standart Deviasi & 14.2 & 1.78 \\
Minimum & 28.57 & 78.57 \\
Maximum & 96.43 & 82.14 \\
\hline Kategori Mean & Efektif & Efektif \\
\hline
\end{tabular}

Tabel 7. Distribusi Frekuensi Keefektifan Tindak lanjut Supervisi Akademik Oleh Kepala Sekolah menengah Kejuruan Negeri Kelompok Teknologi dan Rekayasa di Kabupaten Kebumen

\begin{tabular}{lcccc}
\hline \multicolumn{1}{c}{ Tindak Lanjut } & \multicolumn{3}{c}{ Sumber Data } \\
$\quad$ Supervisi & Guru & \multicolumn{2}{c}{ Kepala } \\
Akademik & & \multicolumn{3}{c}{ Sekolah } \\
& $\mathrm{f}$ & $\%$ & $\mathrm{f}$ & $\%$ \\
\hline Sangat Efektif & 55 & 39 & 1 & 25 \\
Efektif & 61 & 42 & 3 & 75 \\
Cukup Efektif & 25 & 18 & 0 & 0 \\
Kurang Efektif & 1 & 1 & 0 & 0 \\
Tidak Efektif & 0 & 0 & 0 & 0 \\
\hline Total & 142 & 100 & 4 & 100 \\
\hline
\end{tabular}

Tabel 6 dan 7memperlihatkan bahwa keefektifan perencanaan supervisi akademik oleh Kepala Sekolah Menengah Kejuruan Negeri Kelompok Teknologi dan Rekayasa di Kabupaten Kebumen berada pada kategori sangat efektif dengan tingkat pencapaian menurut persepsi guru reratanya sebesar 75 dan menurut persepsi kepala sekolah pencapaian reratanya sebesar 79,46 . Artinya kepala sekolah telah melaksankan tindak lanjut supervisi akademik dengan efektif. Dengan tindak lanjut yang efektif ini dapat membantu guru untuk mengembangkan profesionalisme. Sebanyak $70 \%$ responden menyatakan dalam tindak lanjut supervisi kepala sekolah selalu melaksanakan analisis dan evaluasi hasil supervisi. Dalam hal pelaporan supervisi $70 \%$ responden menyatakan kepala sekolah sering membuat laporan supervisi akademik. Sebanyak 70\% responden menyatakan kepala sekolah selalu melaksanakan tindak lanjut supervisi yaitu dengan pembinaan dan merancang kembali program supervisi, dapat dikatakan bahwa kepala sekolah setelah melaksanakan supervisi kemudian melakukan pembinaan kepada guru-guru dan merancang kembali merancang kembali program supervisi untuk tahun berikutnya.

Hal lain yang terkait dengan supervisi adalah pelaporan hasil pelaksanaan supervisi. Pelaporan ini untuk melihat keberhasilan-keberhasilan yang telah dicapai. Pentingnya laporan menurut pendapat Mohanty ( Dirjen PTK 2008, p. 2) sebagai berikut.

Inspection report is are the most fundamental and usefil record and like mirrors they reflect the quality of supervision. The inspection report also indicate the method comprehensiveness and frequencies of visits. From there evidence the effectiveness of supervision can be judged to a grest extent.

Berdasakan pendapat tersebut dapat dipahami bahwa pelaporan merupakan catatan fundamental (mendasar) dan berguna bagaikan cermin yang menunjukkan kualitas supervisi. Laporan tersebut juga dapat menunjukkan seberapa komprehensif metode supervisi yang dilakukan dan seberapa tinggi kunjungan supervisor (kepala sekolah) dalam rangka melaksanakan supervisi. Berdasarkan data penelitian setelah melaksanakan supervisi kepala sekolah membuat laporan hasil kegiatan supervisi untuk diserahkan kepada pengawas, agar dapat digunakan sebagai dasar untuk melaksanakan pembinaan terhadap guru.

\section{Simpulan dan Saran}

Simpulan

Berdasarkan analisis hasil penelitian dan pembahasan diatas dapat disimpulkan bahwa: Persepsi guru dan kepala sekolah 
terhadap perencanaan supervisi akademik dalam rangka peningkatan profesionalisme guru menunjukkan kategori sangat efektif dengan rerata skor menurut persepsi guru sebesar 88,20 dan menurut kepala sekolah sebesar 90,62. Persepsi guru dan kepala sekolah terhadap pelaksanaan supervisi akademik dengan menggunakan teknik dan pendekatan yang tepat dalam rangka untuk meningkatkan profesionalisme guru menunjukkan kategori efektif, dengan ratarata skor menurut guru 77,02 dan menurut kepala sekolah 79,96. Kepala sekolah mempunyai kemampuan dalam memilih teknik dan pendekatan dalam supervisi akademik. Persepsi guru dan kepala sekolah terhadap tindak lanjut supervisi akademik oleh kepala sekolah pada kategori efektif, dengan rerata skor menurut guru 75 dan menurut kepala sekolah 79,46. Kepala sekolah setelah melakukan supervisi akademik melakukan tindak lanjut berupa pembinaan dan pelaporan kepada pengawas, serta merancang kembali program supervisi untuk tahun berikutnya.

Saran

Berdasarkan hasil penelitian dan simpulan yang telah dipaparkan dapat disampaikan beberapa saran sebagai berikut. Pertama, hasil supervisi akademik perlu ditindaklanjuti dengan mengajak guru berdiskusi untuk memecahkan masalah yang berkaitan dengan pembelajaran agar tujuan pendidikan dapat tercapai. Kedua, guru harus meningkatkan dan memperbaiki kinerjanya dengan cara sepenuh hati melaksanakan hasil bimbingan dan pembinaan yang telah dilakukan oleh kepala sekolah sebagai hasil dari kegiatan supervisi akademik. Ketiga, pelaksanaan kegiatan pembinaan perlu ditingkatkan dan dipertahankan agar kegiatan supervisi tidak menjadi kegiatan yang menakutkan melainkan suatu kegiatan kebutuhan bagi guru untuk mengatasi permasalahan pembelajaran. Keempat, sebaiknya kepala sekolah tidak hanya memberikan saran atau masukan terkait dengan cara mengajar guru, namun juga memberikan contoh cara mengajar yang baik dan benar sehingga dapat mem- buat siswa lebih aktif dan kreatif. Kelima, diharapkan untuk penelitian selanjutnya dapat meneliti kompetensi supervisi akademik dengan lebih dalam dan lebih luas.

\section{Daftar Pustaka}

Arikunto, S. (2010). Prosedur penelitian: Suatu pendekatan praktik. Jakarta: Rineka Cipta

Arikunto, S \& Abduljabar. C. S. (2011). Evaluasi Program Pendidikan. Jakarta: Bumi Aksara

Dasrizal. (2009). Pentingnya supervisi pendidikan sebagai upaya peningkatan profesionalisme guru. Jurnal Guru, No. 1, Volume 6. Dinas Pendidikan Kota Padang Panjang.

Hawkins, P. \& Shohet, R. (2012). Supervision in the helping professions. England: Open University Press.

Kemendiknas (2007). Peraturan Menteri Pendidikan Nasional Nomor 13 Tahun 2007, Tanggal 17 April 2007, Tentang Standar Kepala Sekolah/Madrasah.

Kemendiknas. (2010). Supervisi akademik kepala sekolah, Jakarta: Direktorat Jenderal Peningkatan Mutu Pendidik dan Tenaga Kependidikan Kementrian Pendidikan Nasional.

Kemendiknas. (2011). Supervisi akademik. Materi Pelatihan Penguatan Kemampuan Kepala Sekolah. Pusat Pengembangan Tenaga Kependidikan dan Penjaminan Mutu Badan Pengembangan Sumber Daya Manusia Kementrian Pendidikan Nasional.

Lopez, O. S. (2007). Classroom diversification: A review of theory, ideology, and research. Journal of American Educational Research Association. Volume 77 Number 1 March 2007. Los Angeles: SAGE Publication.

Makawimbang, J. H. (2011). Supervisi dan peningkatan mutu pendidikan. Bandung: Alfabeta. 
Makawimbang, J. H. (2012). Kepemimpinan pendidikan yang bermutu. Bandung: Alfabeta.

Panigrahi, M. R. (2012). Implementation of instructional supervision in secondary school: Approaches, praspects and problems. Ethiopia: Haramaya University.

Pidarta, (2009). Supervisi pendidikan kontekstual. Jakarta: Rineka Cipta

Purwanto, M. N. (2012). Administrasi dan supervisi pendidikan. Bandung: Remaja Rosda Karya
Republik Indonesia. (2003). Undang Undang RI No. 20 Tahun 2003, tentang Sistem Pendidikan Nasioanal.

Republik Indonesia. (2005). Undang Undang RI No. 14 Tahun 2005, tentang Guru dan Dosen.

Sugiyono. (2012). Metode penelitian pendidikan. Bandung: Alfabeta

Sullivan, S \& Glanz, J. (2005). Supervision that improves teaching: Strategies $\mathcal{E}$ techniques $\left(2^{\text {nded }}\right)$. Thousand Oaks, California: Corwin Press. 